\title{
DAMPAK MODEL PENDIDIKAN KELUARGA TERHADAP KONDISI PSIKOLOGIS DAN KEMANDIRIAN ANAK
}

\author{
Achmat Mubarok \\ Universitas Yudharta Pasuruan \\ mubarok@yudharta.ac.id
}

\begin{abstract}
Parents have a very important role in the continuity of a child's life in a family. The behaviors, attitudes, and ordinances of life made by parents are the elements of

Received: education that will indirectly enter into the child's behavior. Therefore, parents should April 23 2020 always give examples and a good example to the child in behaving. The study and discussion in this study on the impact of the family education model on the psychological

Revised: and self-reliance conditions of the child and the constraints faced by parents in the May $19^{\text {th }} 2020$ implementation of family education. The family education Model is very influential in the development and growth of children, especially in the absence. The Model of Family education implementation is done by adjusting to the situation and condition of children Accepted: and based on the context of the needs and abilities of the child through the provision of June $26^{\text {th }} 2020$ a set of rules that are accompanied by the provision of good motivation, the giving of the good dowager or manners, and the depth of the religious sciences owned by the parents will give a good impact on the psychological and independence, just as a child will be more controlled in prayer, diligent manners in carrying out daily and responsible tasks. The obstacles faced by parents in the implementation of family education require bigh process and patience, transparency, have scholarly discipline to accompany and guide the child, especially for the busy parents in the work.

Keywords: Family education Model, psychological condition, child independence
\end{abstract}

\section{PENDAHULUAN}

Pendidikan memiliki peran penting dalam menunjang kemajuan suatu bangsa dan negara, semakin maju keberadaan pendidikan di suatu bangsa maka akan semakin tinggi pula tingkat perekonomian bangsa yang bersangkutan. ${ }^{1}$ Begitu pula pentingnya masalah model pendidikan yang dilakukandi dalam keluarga yang dapat memberikan dampak terhadap perkembangan kemandirian, pertumbuhan jasmani dan rohani, sehingga dapat berguna bagi diri sendiri, masyarakat, bangsa dan negara serta agama. ${ }^{2}$ Pendidikan untuk anak dimulai dari pendidikan dalam keluarga, apabila anak mendapat pendidikan yang baik dalam keluarga maka dapat diharapkan anak punya kemandirian dari dasar yang dimulai dari keluarga atau orang tua, segala usaha yang dilakukan memiliki pengaruh serta dampak di dalam perkembangan jasmani dan rohaninya ke arah kedewasaan. ${ }^{3}$

Prinsip dasar tentang pelaksanaan pendidikan di dalam keluarga adalah: Pertama pendidikan akan berlangsung seumur hidup, usaha pendidikan sudah dimulai sejak manusia lahir dari kandungan ibunya, sampai tutup usia, sepanjang ia mampu untuk menerima pengaruh dan dapat mengembangkan dirinya.

\footnotetext{
1 Abu Ahmadi dan Nur Ubhiyati, Ilmu Pendidikan, Jakarta: Rineka Cipta, 1991, Hal: 70.

2 Vrembianto, Sosiologi Pendidikan, Yogyakarta Gunung Agung, 1990. Hal : 35.

${ }^{3}$ Uyoh Sadulloh, Ilmu Pendidikan Islam, Bandung: Alfabeta, 2003, Hal: 56.
} 
Suatu konsekuensi dari konsep pendidikan sepanjang hayat adalah, bahwa pendidikan tidak identik dengan persekolahan. Pendidikan akan berlangsung dalam lingkungan keluarga, sekolah dan masyarakat. Kedua, bahwa tanggung jawab pendidikan merupakan tanggung jawab bersama semua manusia, yakni tanggung jawab orang tua, tanggung jawab masyarakat, dan tanggung jawab pemerintah. Bersama keluarga dan masyarakat, pemerintah berusaha semaksimal mungkin agar pendidikan mencapai tujuan yang telah ditetapkan. Ketiga, bagi manusia pendidikan merupakan suatu keharusan, karena dengan pendidikan manusia akan memiliki kemampuan dan kepribadian yang berkembang, yang disebut manusia seutuhnya. ${ }^{4}$

Peranan orang tua dalam mengarahkan anaknya untuk memiliki kebebasan mengenal dirinya agar menjadi pribadi yang mandiri dalam segala hal seperti halnya orang tua harus mampu menanamkan pendidikan keagamaan yang dimulai sejak dini, dengan mengajarkan dan mengontrol untuk melakukan shalat lima waktu setiap hari, melakukan kegiatan keagamaan lainnya, Saling tolong menolong pada semua teman, menanamkan masalah keimanan, melaksanakan perintah agama pada diri anak agar anak mampu melakukannya setiap hari tanpa ada beban dan paksaan dari orang tua. Orang tua dapat bekerja sama dalam menyampaikan pesan-pesan spiritual pada anak dengan maksud memperkenalkan konsep menyeluruh tentang spiritualitas.

Pendidikan keluarga yang diberikan kepada anak, harus mengarah pada pembentukan pribadi muslim yang taat, berilmu dan beramal. Oleh karena itu orientasi pendidikan keluarga yang diberikan kepada anak sejak dini, selain terbentuknya aspek kognitif dan psikomotor yang lebih penting adalah aspek penghayatan, sehingga anak dapat meiliki pengetahuan, penghayatan dan kemudian anak dapat memiliki pengetahuan itu serta mengamalkannya dalam kehidupan sehari-hari, pendidikan keluarga merupakan bagian dari jalur pendidikan luar sekolah yang diselenggarakan dalam keluarga dan meberikan keyakinan agama, nilai budaya, nilai moral dan keterampilan. ${ }^{5}$

Salah satu hambatan dalam pelaksanaan pendidikan di dalam keluarga yang paling umum terjadi yakni masalah komunikasi antara orang tua dan anak, hubungan yang semakin lama semakin merenggang dapat menghambat pendidikan informal yang terjadi di dalam keluarga. Hubungan yang merenggang tersebut menjadi penyebab sikap terbuka anak kepada orang tua semakin hilang, jika interaksi yang terjadi di antara orang tua dan anak tidak baik, maka harapan dan tujuan orang tua kepada anak semakin sulit untuk dicapai. Orang tua memiliki berbagai karakter masing-masing dalam menyampaikan nasihat atau pengarahan terhadap anaknya, terkadang anak memiliki rasa tidak suka terhadap cara penyampaian orang tua yang tidak cocok dengan kondisi anak, hal ini dapat menghambat proses penyampaian nasihat atau pengarahan terhadap anak. Begitu pula sebaliknya, orang tua yang tidak suka terhadap sikap anak yang

\footnotetext{
${ }^{4}$ M. Ngalim Purwanto, Ilmu Pendidikan Teoritis dan Praktis, Bandung: Remaja Rosda Karya, 1991, hal :14.

${ }^{5}$ Undang-undang RI, No. 20 Tahun 2003, Tentang Sistem Pendidikan Nasional, Intan Pariwara, Jakarta, hal: 11.
} 
menerima nasihat dapat menimbulkan kesalahpahaman antara orang tua dan anak. Jika interaksi ini tidak terjalin baik maka dapat menimbulkan rasa tidak suka di antara kedua pihak.

Menemukan sifat kemandirian pada diri anak sejak diri akan melatih anak berusaha untuk menjadi tidak bergantung pada orang lain. Semakin bertambah usia, kemampuan fisik dan psikisnya semakin berkembang sehingga anak mulai ingin memisahkan diri dan tidak bergantung pada orang lain tapi mampu untuk mencari apa yang diinginkan. ${ }^{6}$ Secara psikologis setiap anak akan mengembangkan rasa tanggung jawab dan kemandirian seiring dengan perkembangan emosi dan sosial, orang tua harus tanggap terhadap tanda-tanda kemandirian yang ditunjukkan oleh anak, orang tua menyarankan menjadi mandiri berarti harus mampu mengajarkan pada anak untuk mengetahui batas-batas yang boleh dilakukan dan yang tidak boleh dilakukan. Dukungan dari ibu, ayah atau saudara-saudara untuk memberikan latihan kemandirian sejak dini agar anak memiliki kesempatan untuk memilih jalan sendiri dan berkembang, punya rasa tanggung jawab baik dalam tingkah laku atau perbuatnnya dilingkungan keluarga ataupun dilingkungan sekolah.

Kemandirian berarti mampu melakukan aktifitas, inisiatif, belajar, mengatur tingkah laku, kemampuan membuat keputusan-keputusan sendiri mengerjakan tugas-tugas rutin yang dilakukan setiap hari, keluarga mempunyai peran yang sangat penting untuk menunjang kemandirian dalam diri anak sejak dini temasuk keharmonisan sebuah keluarga yang ditandai dengan kedua orang tua dengan menerapkan strategi, metode-metode yang membuat anak tidak merasa tertekan atau tidak bebas.

Kemandirian berawal dari kebiasaan atau kemampuan anak untuk berdiri sendiri tidak tergantung dengan orang lain berupa kedisiplinan yang diterapkan oleh orang tua sejak dini dengan cara menerapkan strategi dan metode yang membuat anak-anak akan belajar untuk memahami pentingnya kedisiplinan untuk anak mereka sendiri., misalnya kedisiplinan dalam belajar yang akan menunjang prestasi mereka, contohnya mengerjakan pekerjaan rumah tanpa disuruh orng tua, sebab mereka tahu apa akibat yang akan diterima jika tidak melakukan pekerjaan rumah, merapikan buku-buku sekolah agar tidak ada yang tertinggal dan masih banyak contoh-contoh yang lain tentang kedisiplinan belajar disekolah atau disiplin belajar dirumah.

Berdasarkan uraian diskripsi pendahuluan di atas, peneliti tertarik untuk melakuakan kajian tentang model pelaksanaan pendidikan keluarga, dampak yang ditimbulkan dari model pendidikan keluarga, serta kendala dalam pelaksanaan pendidikan keluarga siswa SMA di dusun Jati Gunting Wonorejo.

\footnotetext{
${ }^{6}$ Soekanto Soerjono, Sosiologi Keluarga, Jakarta: Rineka Cipta, 1990. Hal: 19.

${ }^{7}$ Helmawati, Pendidikan Keluarga, PT. Remaja Rosdakarya, Bandung: 2014, hal: 50.
} 


\section{METODE}

Berdasarkan pada fokus penelitian, maka pendekatan yang digunakan dalam penelitian ini menggunakan pendekatan studi kasus pada siswa SMA di dusun Jati Guting dengan disain berbentuk funnel yang dilakukan melalui proses penelitian yang berawal dari eksplorasi umum tentang model pendidikan keluarga yang terjadi secara luas dan mendalam, kemudian berlanjut ke aktivitas pengumpulan data, dan hasilnya dianalisis yang lebih menyempit dan terarah pada suatu topik tertentu, sehingga tersusunlah teori sementara tentang model pendidikan beserta pola-pola yang diterapkan dalam pendidikan keluarga di lokasi penelitian. Strategi penelitian ditempuh melalui orientasi teoritik fenomenologis yang akan mengutamakan pada fenomena yang terjadi di lapangan berdasarkan pada bagaimana persepsi dan makna menurut sudut pandang partisipan yang diteliti, kehadiran peneliti di lapangan dengan melakukan tahapan-tahapan penelitian, data primer diperoleh melalui informan dari orang tua wali siswa SMA di dusun Jati Gunting. Untuk teknik pengumpulan data didasarkan atas sumber data, tehnik yang digunakan peneliti dengan cara memberikan kesempatan pada informan untuk mengungkapkan pengalaman dan pengamatannya, selanjutnya ditarik sebuah deskriptif data untuk diadakan pengamatan lapangan serta melibatkan dari dalam peran atau ikut serta, serta studi dokumentasi dalam bentuk penyajian data dan gambar. Sesuai dengan pendekatan dan jenis penelitian, maka pengumpulan data dalam penelitian ini menggunakan tiga teknik yakni dengan pengumpulan data melalui wawancara, observasi, dan dokumentasi. Tehnik analisis data dilakukan melalui: (1) reduksi data dengan cara menggolongkan, mengarahkan, membuang yang tidak perlu, dan mengorganisir data; (2) penyajian data, yaitu: menemukan pola-pola hubungan yang bermakna serta memberikan kemungkinan adanya penarikan kesimpulan; (3) penarikan kesimpulan/verifikasi. Pengecekan keabsahan data dilakukan bersama-sama pengumpulan data, dan setelah semua data terkumpul, selanjutnya diterapkan tehnik triangulation, dan peer debriefing.

\section{HASIL DAN PEMBAHASAN}

Pembentukan kepribadian pertama bagi seorang anak bermula dari pendidikan yang terjadi di tengah-tengah keluarga. Pola pendidikan keluarga terhadap anak-anaknya sangat menentukan dan mempengaruhi kepribadian (sifat) serta perilaku anak. anak menjadi baik atau buruk semua tergantung dari pola pendidikan orang tua dalam keluarga. Berikut ini diuraikan macam-macam model pendidikan keluarga terhadap anak: ${ }^{8}$

1. Pola Pendidikan Demokratis

\footnotetext{
${ }^{8}$ Syamsu Yunuf, Psikologi Perkembangan Anak dan Remaja, Bandung: PT Remaja Rosda Karya, 2005, hal: 50.
} 
Pola pendidikan yang memprioritaskan kepentingan anak tetapi tidak ragu untuk mengendalikan mereka pula. Jika anak-anak dibesarkan dan dididik dengan pola pendidikan yang demokratis, niscaya dapat tumbuh dan berkembang dengan baik. Seluruh potensi yang dimiliki anak dapat dikembangkan secara optimal. Dengan demikian pada gilirannya nanti akan menumbuhkan anak-anak yang sehat, cerdas, ceria dan berakhlak mulia dapat terwujud. Dampak positif yang muncul adalah terwujudnya suatu tatanan masyarakat yang baik, saling menghargai, saling menghormati, saling menyayangi, saling mengasihi, berpikir positif, jujur, dan mempunyai toleransi yang baik.

\section{Pola Pendidikan Otoriter}

Dalam pola pendidikan ini orang tua menerapkan seperangkat peraturan kepada anaknya sehingga secara ketat dan sepihak, cenderung menggunakan pendekatan yang bersifat diktator, menonjolkan wibawa, menghendaki ketatan mutlak. Anak harus tunduk dan patuh terhadap kemaun orang tua. Apaun yang dilakukan oleh anak ditentukan oleh orang tua. Anak tidak mempunyai pilihan dalam melakukan kegiatan yang ia inginkan, karena semua sudah ditentukan oleh orang tua. Tugas dan kewajiban orang tua tidak sulit, tinggal menentukan apa yang diinginkan dan harus dilakukan atau yang tidak boleh dilakukan oleh anak. Selain itu, mereka beranggapan bahwa orang tua harus bertanggung jawab penuh terhadap perilaku anak dan menjadi orang tua yang otoriter merupakan jaminan bahwa anak akan berperilaku baik. Orang tua yakin bahwa perilaku anak dapat diubah sesuai dengan keinginan orang tua dengan cara memakskan keyakinan, nilai, perilaku dan standar perilaku kepada anak yang dibesarkan dalam keluarga otoriter cenderung merasa tertekan, dan penurut. Mereka tidak mampu mengendalikan diri, kurang dapat berpikir, kurang percaya diri, tidak bisa mandiri, kurang kreatif, kurang dewasa dalam perkembangan moral, dan rasa ingin tahunya rendah.

3. Pola Pendidikan Permisif

Pola pendidikan ini memperlihatkan bahawa orang tua cenderung memberikan banyak kebebasan kepada anaknya dan kurang memberikan kontrol. Orang tua banyak bersikap membiarkan apa saja yang dilakukan anak. Orang tua bersikap damai dan selalu menyerah pada anak untuk menghindari konfrontasi oramg tua kurang memberikan bimbingan dan arahan kepada anak. Anak dibiarkan berbuat sesuka hatinya untuk melakukan apa saja yang mereka inginkan. Orang tua tidak peduli apakah anak melakukan hal-hal yang positif atau negatif, yang penting hubungan antara anak dengan orang tua baik-baik saja, dalam arti tidak terjadi konflik dan tidak ada masalah antara keduanya.

4. Pola Pendidikan Otoritatif

Dalam pola pendidikan ini, orang tua memberi kebebasan yang disertai bimbingan kepada anak. orang tua banyak memberi masukan-masukan dan arahan terhadap apa yang dilakukan oleh anak. orang tua bersifat obyektif, perhatian dan kontrol terhadap perilaku anak. dalam banyak hal orang tua sering berdialog dan berembuk dengan anak tentang berbagai keputusan. Menjawab petanyaan anak dengan 
bijak dan terbuka. Orang tua cenderung menganggap sedeajat hak dan kewajiban anak dibanding dirinya. Pola pendidikan ini menempatkan musyawarah sebagai pilar dalam memecahkan berbagai persoalan anak, mendukung dengan penuh kesadaran dan berkomunikasi dengan baik. Pola otoritatif mendorong anak untuk mandiri, tetapi orang tua haus tetap menetapakn batas dan kontrol. Orang tua biasanya bersikap hangat, dan penuh belas kasih kepada anak, bisa menerima alasan dari semua tindakan anak, mendukung tindakan anak yang konstruktif. Anak yang terbiasa dengan pola pendidikan otoritatif akan membawa dampak menguntungkan. Diantaranya anak akan merasa bahagia, mempunyai kontrol diri dan rasa percaya diri terpupuk, bisa mengatasi stres, punya keinginan prestasi, dan bisa berkomunikasi, baik dengan teman-teman dan orang dewasa. Anak lebih kreatif, komunikasi lancar, tidak rendah diri, dan berjiwa besar. Penerapan pola otoritatif berdampak positif terhadap perkembangan anak kelak, karena anak senantiasa dilatih untuk mengambil keputusan dan siap menerima segala konskuensi dari keptusan yang diambil. ${ }^{9}$

Pola pendidikan keluarga yang berkembang di masyarakat ditentukan oleh struktur keluarga dan domisi keluarga dalam seting masyarakatnya. Dalam hal ini keluarga dapat dikategorikan pada keluarga yang berada pada masyarakat pedesaan dengan bercirikan paguyuban, dan keluarga masyarakat perkotaan yang bercirikan patembayan. Keluarga pedesaan memiliki karakter keakraban antar anggota keluarga yang lebih luas dengan intensitas relasi yang lebih dekat, sedangkan keluarga perkotaan biasanya memiliki relasi lebih longgar dengan tingkat intensitas pertemuan lebih terbatas. ${ }^{10}$

Dalam perkembangannya, kategori pedesaan dan perkotaan menjadi bergeser karena dipengaruhi oleh peran-peran anggota keluarga yang turut bergeser pula. Dahulu konsep pencari nafkah dibebankan pada suami dengan status kepala keluarga namun pergeseran kehidupan keluarga pada masyarakat tradisional menjadi masyarakat urban modern dapat mengubah gaya hidup, peran-peran sosial, jenis pekerjaan dan volume serta wilayah kerja yang tidak dapat dipisahkan secara dikotomis. ${ }^{11}$

Tujuan Pendidikan Keluarga hendaknya mengarah kesana, yaitu terciptanya insan pengabdi, yang hanya mengabdikan diri kepada Allah. Kamrani mengatakan bahwa tujuan pendidikan keluarga adalah untuk mewujudkan keluarga sakinah, mawaddah dan rahmah atau menjadi keluarga yang tentram saling mengasihi dan saling menyayangi sehingga menjadi keluarga yang sejahtera dan bahagia. ${ }^{12}$

Bentuk-bentuk Pendidikan Keluarga dapat di bagi menjadi tiga kategori, yaitu: 1) keluarga inti, yang terdiri dari bapak, ibu dan anak-anak, atau hanya ibu atau bapak atau nenek dan kakek; 2) keluarga inti terbatas, yang terdiri dari ayah dan anak-anaknya, atau ibu dan anak-anaknya; 3) keluarga luas, yang cukup banyak ragamnya seperti rumah tangga nenek yang hidup dengan cucu yang masih sekolah, atau nenek

\footnotetext{
${ }^{9}$ Syamsu Yunuf, Psikologi Perkembangan Anak dan Remaja. Bandung: PT Remaja Rosda Karya, 2005, hal: 54.

${ }^{10}$ Mufidah ch, Psikologi Keluarga Islam Berwawasan Gender, Malang: UIN Malang Press, 2008, cet. Ke-1, hal:41.

${ }^{11} \mathrm{Ibid}$, hal: 42.

${ }^{12} \mathrm{Ibid}$, hal: 25 .
} 
dengan cucu yang telah kawin, sehingga isteri dan anak-anaknya hidup menumpang juga. ${ }^{13}$ Tujuan terpenting dari pembentukan keluarga adalah: 1) mendirikan syariat Allah, berarti mendirikan rumah tangga muslim yang mendasar kehidupannnya pada perwujudan kepada Allah. Dan sangat mudah anakanak akan meniru kebiasaan orang tua dan akhirnya terbiasa hidup Islam; 2) mewujudkan ketentraman ketenangan psikologis, berarti anak-anak akan tumbuh dalam suasana bahagia, percaya diri, kasih sayang, kesulitan dan penyakit batin yang melemahkan kepribadian anak; 3) mewujudkan sunnah Rasulullah saw dengan melahirkan anak soleh; 4) memenuhi kebutuhan cinta kasih anak-anak.

Adapun kondisi psikologi pendidikan dalam tahapan pendidikan menurut teori psikologi, ada tiga macam: 1) mengenai "belajar", yang meliputi teori-teori prinsip, dan ciri-ciri khas perilaku belajar peserta didik, dan sebagainya; 2) mengenai proses belajar, yakni tahapan perbuatan dan peristiwa yang terjadi dalam kegiatan belajar; 3) mengenai situasi belajar, yakni suasana dan keadaan lingkungan, baik bersifat fisik maupun nonfisik yang berhubungan dengan kegiatan belajar.

Kemandirian merupakan salah satu aspek kepribadian yang sangat penting bagi individu. Dalam menjalani kehidupan ini individu tidak pernah lepas dari cobaan dan tantangan. Individu yang memiliki kemandirian tinggi relatif mampu menghadapi segala permasalahan karena individu yang mandiri tidak tergantung pada orang lain, selalu berusaha menghadapi dan memecahkan masalah yang ada. Belajar mandiri diawali dengan pembiasaan-pembiasaan pada diri anak sejak dini yaitu dimulai dari lingkungan keluarga sekolah dan lingkungan sekitarnya untuk melakukan hal-hal yang tertib, baik dan teratur. Pembiasaan yang baik penting artinya bagi pembetukan watak anak-anak sejak awal sampai di hari tuanya nanti. Selain menerapkan pembiasaan pada diri anak harus ada pembuktian seperti contoh dan tauladan. Sebab fitrah manusia baik yang kecil dan dewasa telah mempunyai dorongan meniru dan suka mengindentifikasikan diri terhadap perbuatan dan tingkah laku orang lain terutama orang tua dan pendidik serta teman-teman sebayanya. ${ }^{14}$

Beberapa aspek-aspek kemandirian yang dapat diidentifikasi yaitu: 1) kemandirian Emosi (Emotional Autonomy), kemandirian emosi didefinisikan sebagai sebuah aspek dari kemandirian yang berhubungan dengan perubahan hubungan individual dengan orang-orang terdekat, terutama orang tua. Pada akhir tahapan remaja, seseorang menjadi lebih tidak bergantung secara emosinal terhadap orang tunya, daripada saat mereka masih kanak-kanak. Perubahan hubungan dengan orang tua inilah yang dapat disebut sebagai perkembangan dalam hal kemandirian emosional, walaupun demikian kemandirian remaja tidak membuat remaja tersebut terpisah dari hubungan keluarganya. Jadi seorang remaja tetap dapat menjadi mandiri tanpa harus terpisah hubungan dengan keluarganya; 2) Kemandirian Perilaku (behavioral Autonomy), kemandirian perilaku diartikan sebagai kapasitas untuk membuat keputusan-keputusan dengan mandiri

\footnotetext{
13 Atashendartini Habsjah, Jender dan Pola Kekerabatan dalam TO Ibromi, Jakarta: Yayasan Obor Indonesia, 2004, hal : 218.
}

${ }^{14}$ Soekanto Soerjono , Sosiologi Keluarga, Jakarta: Rineka Cipta, 1990. Hal: 19. 
dan amelaksanakan keputusannya tersebut. Kemandirian tingkah laku dapat dilihat dari tiga perubahan yang muncul pada saat remaja, 3) kemandirian Kognitif(Cognitive Autonomy) atau Kemandirian Nilai (Value Autonomy), perubahan kognitif atau yang juga disebut sebagai kemandirian nilai pada remaja mendapat peran penting dalam perkembangan kemandirian, karena dalam kemandirian dibutuhkan kemampuan untuk membuat keputusan sendiri. Pada perkembangan dari kemandirian nilai, terjadi perubahan dalam konsep remaja tentang moral, politik, ideologi, dan isu tentang agama.

Dalam mencapai kemandirian seseorang tidak terlepas dari faktor-faktor yang mendasari terbentuknya kemandirian itu sendiri. Faktor-faktor yang mempengaruhi kemandirian sangat menentukan sekali tercapainya kemandirian seseorang baik faktor yang berasal dari dalam seseorang itu sendiri maupun yang berasal dari luar yaitu lingkungan keluarga, sekolah, lingkungan sosial ekonomi dan lingkungan masyarakat. Faktor-faktor tersebut mempunyai peranan yang sangat penting dalam kehidupan yang selanjutnya akan menentukan seberapa jauh seorang individu bersikap dan berpikir secara mandiri dalam kehidupan lebih lanjut. Beberapa faktor yang mempengaruhi kemandirian anak adalah: Keluarga: misalnya pola asuh orang tua; Sekolah: perlakuan guru dan teman sebaya; Media komunikasi massa: misalnya majalah, koran, televisi dan sebagainya; Agama: misalnya sikap terhadap agama yang kuat pekerjaan atau tugas yang menuntut sikap pribadi tertentu.

Keluarga merupakan merupakan lingkungan yang pertama bagi anak. Di dalam lingkungan keluarga anak pertama-tama mendapatkan berbagai pengaruh (nilai). Oleh karena itu, keluarga meruapakan lembaga pendidikan tertua yang bersifat informal dan kodrati. Ayah dan ibu dalam keluarga sebagai pendidiknya, dan anak sebagai si pendidiknya. ${ }^{15}$ Keluarga sebagai lingkungan pendidikan yang pertama sangat bepengaruh dalam membentuk pola kepribadian anak. Di dalam keluarga anak pertama kali berkenalan dengan nilai dan norma. Pendidikan keluarga memberikan pengetahuan dan keterampilan dasar, agama dan kepercayaan, nilai-nilai moral, norma sosial dan pandangan hidup yang diperlukan anak. ${ }^{16}$ Dalam keluarga sebagai salah satu institusi pendidikan yang kaut dan mendasar, peran kedua orangtua sangat menentukan, yaitu sebagai contoh dan suri teladan bagi anak-anaknya.

Untuk membentuk anak yang mandiri, orang tua perlu memberi kesempatan kepada anak untuk mencoba sesuatu, misalnya birkan anak mencoba untuk makn sendiri, meski pada umunya akan berantakan. Orang tua perlu memberikan kesempatan pada anak untuk tetap berlatih, disamping untuk mencaba, orang tua juga perlu mengajar untuk memilih yang ia inginkan. ${ }^{17}$ Orang tua harus mengetahui bahan anak itu membutuhkan pengalaman buruk ataupun pengalaman baik. Maka anak akan tumbuh dengan penuh rasa aman dan mempunyai rasa percaya diri yang kuat untuk melakukan apa yang di inginkan. Tugas orang tua adalah mendorong anak itu belajar melakukan sendiri serta punya tanggung

\footnotetext{
${ }^{15}$ Helmawati, Pendidikan Keluarga, PT. Remaja Rosda Karya, Bandung: 2014, hal: 50.

${ }^{16}$ Ibid, hal: 54.

${ }_{17}$ Alex Sobur, Komunikasi Orang Tua \& Anak, Bandung: Angkasa, 1986, hal: 66.
} 
jawab terhadap apa yang ia lakukan, baik di sekolah maupun dirumah, asalkan tidak terlalu membebani anak. Cara terbaik untuk menumbuhkan kemandirinnya adalah dengan menciptakan suasana yang menunjang perkembangan rasa percaya diri serta harga diri anak dengan keluarga. Anak usia remaja kadang ia merasakan kebutuhan akan keberatan dan menuntut kemerdekaan penuh. Ia ingin membuat keputusan sendiri, ia ingin mengurus dirinya sendiri, merasa jenuh dengan pengendalian orang tua dan berusaha membuktikan bahwa ia bukan kana-kanak lagi. Ia ingin memenuhi kebutuhannya sendiri dengan menunjukkan kemampunnya dengan ditandai: 1) mampu mengerjakan tugas-tugas rutinnya sehari-hari tanpa bergantung dengan orang lain; 2) aktif, yang ditunjukkan dengan adanya usaha untuk mengejar prestasi berarti ia harus punya kreatif-kreatif sendiri dalam belajar, untuk mewujudkan cita-citanya; 3) punya tanggung jawab dengan menujukkan disiplin dalam belajar; 4) kontrol diri dengan menunjukkan padanya pengendalian emosi kapan waktu ia belajar dan kapan waktu ia bermain, dia dapat membagi waktu dengan baik. ${ }^{18}$

Berdasarkan hasil temuan tentang dampak model pendidikan keluarga terhadap kondisi psikologis dan kemandirian anak, bahwa orang tua yang mempunyai peranan penting dalam proses perkembangan dan pertumbuhan anak, sehingga sangat menentukan berhasil dan tidaknya dalam pendidikan keluarga. Model pendidikan keluarga terhadap anak-anaknya sangat menentukan dan mempengaruhi kepribadian (sifat) serta perilaku anak, seorang anak akan menjadi lebih baik atau tidak semua tergantung dari model pendidikan orang tua dalam keluarga.

Dari penjelasan hasil wawancara beberapa orang tua di desa jati gunting, pola otoritatif dalam model pendidikan keluarga memberikan pengaruh terhadap perkembangan kepribadian seorang anak. Dalam pola pendidikan otoritatif ini menempatkan musyawarah sebagai pilar dalam memecahkan berbagai persoalan anak, mendukung dengan penuh kesadaran dan berkomunikasi dengan baik. Pola otoritatif mendorong anak untuk mandiri, tetapi orang tua haus tetap menetapakn batas dan kontrol. Orang tua biasanya bersikap hangat, dan penuh belas kasih kepada anak, bisa menerima alasan dari semua tindakan anak, mendukung tindakan anak yang konstruktif. Anak yang terbiasa dengan pola pendidikan otoritatif akan membawa dampak menguntungkan. Diantaranya anak akan merasa bahagia, mempunyai kontrol diri dan rasa percaya diri terpupuk, bisa mengatasi stres, punya keinginan prestasi, dan bisa berkomunikasi, baik dengan teman-teman dan orang dewasa. Anak lebih kreatif, komunikasi lancar, tidak rendah diri, dan berjiwa besar. Penerapan pola otoritatif berdampak positif terhadap perkembangan anak kelak, karena anak senantiasa dilatih untuk mengambil keputusan dan siap menerima segala konskuensi dari keptusan yang diambil. Dengan demikian potensi yang dimiliki anak dapat berkembang secara optimal, karena anak melakukan segala aktifitas sesuai drngan kehendak dan potensinya. Sementara orang

\footnotetext{
18 Anas salhuddin, Irwanto Alkrienciehie, Pendidikan Karakter Berbasis Agama dan Budaya Bangsa, Bandung: CV. Pustaka Setia,
} 2013, hal: 240. 
tua memberikan kontrol dan bimbingan manakala anak melakukan hal-hal negatif yang dapat merusak kepribadian anak dalam mendidik anak, orang tua hendaknya bersikap arif dan bijaksana, tidak ekstrim terhadap sala satu pola pendidikan yang ada, dalam arti mampu memberi pendidikan sesuai dengan apa yag sedang dilakukan anak dan apa harapan orang tua. Jadi orang tua dapat menerapkan pola pendidikan tersebut sesuai dengan situasi dan kondisi. ${ }^{19}$

Seperti halnya yang dilakukan oleh informan penelitian memberikan pemahaman dan ilmu sehingga apa yang dilakukan anak-anaknya memiliki dasar keilmuan, mereka meyakini bahwa ilmu merupakan pondasi bagi anak-anaknya untuk melakukan ibadah yang mereka lakukan, dan penanaman ilmu ini hanya bisa dilakukan melalui proses pengajaran, model yang dilakukan orang tua adalah dengan memberikan nasihat-nasihat kepada anak-anaknya. Nasihat yang diberikan oleh orang tua kepada anak anaknya berupa pentingnya membaca dan mengahafal al-Qur'an, kewajiban mengerjakan shalat, keutamaan shalat berjamaah, keutamaan qiyamullail, shalat dhuha,dan puasa sunnah. Pengajaran ini dilakukan secara rutin setelah shalat berjamaah (terutama ba'da maghrib dan subuh), saat sebelum makan bersama, ketika berlibur atau saat anak-anaknya meminta masukkan atau menanyakan sesuatu. ${ }^{20}$ Dengan demikian orang tua memiliki tanggungjawab sekaligus sebagai panutan untuk anak-anaknya dan mendidik mereka untuk memiliki akhlak yang baik, dengan menggunakan nilai-nilai agama yang kuat, mengajari tata krama terhadap orang tua. Namun hal itu orang tua tetap membimbing dan mengarahkan kearah yang benar sehingga akhlak anak itu sendiri akan terbentuk sejak kecil sehingga terbawa samapi dia dewasa nanti.

Berdasarkan hal tersebut maka peneliti menyimpulkan bahwa, yang harus dihindari orang tua adalah model pendidikan yang terlalu berlebihan, karena segala sesuatu yang berlebihan akan menjadi tidak baik. Jadi yang sedang-sedang saja, jika orang tua terlalu ketat atau kaku memberikan peraturan kepada anak sehingga mengekang kebebasannya bisa membuat anak menjadi pemberontak. Jika terlalu memberikan segala sesuatu yang dibutuhkan oleh anak akan membuat anak menjadi tergantung pada orangtua sehingga tidak bisa membuat keputusan sendiri. Sedangkan jika anak dibiarkan terlalu bebas akan membuatnya tidak tahu aturan. Model pendidikan harus disesuaikan dengan konteks kebutuhan dan kemampuan yang dimiliki oleh anak.

Dari paparan di atas, maka sebagai orang tua hendaknya bersikap bijaksana dalam memberikan pendidikan kepada anak-anaknya, dalam arti tidak ekstrim terhadap salah satu pola pendidikan yang ada. Mampu memberikan pendidikan sesuai dengan apa yang sedang dilakukan anak, kapan menerapkan pola pendidikan demokratis, otoriter, permisif, otoritatif. pola pendidikan menjadi empat warna, yaitu warna putih, hijau, kuning dan merah. Jika anak sedang melakukan diwarna putih yaitu kegiatan yang dikehendaki orang tua sesuai dengan situasi dan kondisi. Dengan demikian pendidikan yang diberikan

\footnotetext{
${ }^{19}$ Syamsu Yunuf, Psikologi Perkembangan Anak dan Remaja, Bandung: PT Remaja Rosda Karya, 2005, hal: 50.

${ }^{20}$ Hasil wawancara dengan informan penelitian.
} 
oleh orang tua lebih mengutamakan kasih sayang, kebersamaan, musyawarah, saling pengertian dan penuh keterbukaan, maka dapat menerapkan pola pendidikan otorotatif. Jika anak melakukan kegiatan diwarnai hijau yaitu kegiatan yang dikehendaki orang tua tidak mau pula pusing-pusing memedulikan kehidupan anak, maka dapat menerapkan pola pendidikan permisif. Jika anak melakukan kegiatan di warna merah yaitu kegiatan yang dikehendaki orang tua menerapkan seperangkat peraturan kepada anaknya secara ketat dan sepihak, cenderung menggunakan pendekatan yang bersifat diktator, menonjolkan wibawa, menghendaki ketaatan mutlak. Anak harus tunduk dan patuh terhadap kemauan orang tua, apapun yang dilakukan oleh anak ditentukan oleh orang tua, maka dapat menerapkan pola pendidikan otoriter. Namun apabila melakukan di warna manapun kegiatan (putih, hijau, kuning, merah) sebaiknya pola pendidikan demokratis yang diterapkan orang tua. ${ }^{21}$

Adapun dampak yang timbul dari adanya model pendidikan keluarga yang diterapkan di dusun Jati guntik memiliki pengaruh yang positif, sehingga dapat membentuk kepribadian anak menjadi lebih baik. Berdasarkan pengamatan yang dilakukan peneliti, hal tersebut dapat diketahui dari pola tingkah pada diri anak yang mengarah pada perubahan yang positif, hal tersebut dapat terlihat secara signifikan dari tata cara sopan santun terhadap orang tua, mandiri dalam hal ibadah. Sehingga dampak yang muncul adalah terwujudnya suatu tatanan masyarakat yang baik, saling menghargai, saling menghormati, saling menyayangi, saling mengasihi, berpikir positif, jujur, memiliki kepedulian dan toleransi yang tinggi, serta memiliki kemandirian yang tinggi. Belajar mandiri diawali dengan pembiasaan-pembiasaan pada diri anak sejak dini yaitu dimulai dari lingkungan keluarga sekolah dan lingkungan sekitarnya untuk melakukan halhal yang tertib, baik dan teratur, pembiasaan yang baik bagi pembetukan watak anak sejak awal sampai di hari tuanya nanti. Selain menerapkan pembiasaan pada diri anak harus ada pembuktian seperti contoh dan tauladan. Sebab fitrah manusia baik yang kecil dan dewasa telah mempunyai dorongan meniru dan suka mengindentifikasikan diri terhadap perbuatan dan tingkah laku orang lain terutama orang tua dan pendidik serta teman-teman sebayanya. ${ }^{22}$ Dampak perubahan positif tersebut berbeda dari tingkah laku sebelumnya. Anak tersebut melakukan apa yang telah dinasihati oleh orang tua, walaupun tidak sepenuhnya dikerjakan oleh anak. sholatnya tidak perlu diragukan lagi, setiap kali orang tua melakukan sholat maka anak melakakan hal yang serupa dengannya.

Adapun kendala-kendala yang dihadapi orang tua di dalam penerapan model pendidikan keluarga dari tinjauan waktu, membutuhkan proses yang cukup lama tetapi orang tua tidak patah semangat dalam mengajarkan pada anak-anaknya. Berdasarka hasil temuan di lapangan bahwa pola pedididikan keluarga yang memiliki kesibukan pekerjaan yang cukup tinggi, dan orang tua tidak memiliki disiplin keilmuan dalam membimbing dan mendampingi anak, memiliki dampak negatif terhadap perkembangan

\footnotetext{
${ }^{21}$ Syamsu Yunuf, Psikologi Perkembangan Anak dan Remaja, Bandung: PT Remaja Rosda Karya, 2005, hal: 54.

22 Soekanto Soerjono, Sosiologi Keluarga, Jakarta: Rineka Cipta, 1990. Hal: 19.
} 
kepribadian dan perkembangan psikoliogis anak karena anak akan tumbuh dan berkembang sendiri di lingkungan sekolah dan lingkungan masyarakat tanpa dibarengi dengan bimbingan dan pendampingan orang tuanya, seperti halnya pendampingan masalah agama, masalah tanggungjawab, dan kepedulian sosial. Sedangkan kendala-kendala yang dihadapi seorang anak yakni anak tidak mudah menerima apa yang disampaikan oleh orang tua secara langsung karena membutuhkan proses serta keteladanan dari orang tua. ${ }^{23}$ Kemandirian seorang anaki diawali dengan pembiasaan-pembiasaan pada diri anak sejak dini yaitu dimulai dari lingkungan keluarga sekolah dan lingkungan sekitarnya untuk melakukan hal-hal yang tertib, baik dan teratur. Pembiasaan yang baik penting artinya bagi pembetukan watak anak-anak sejak awal sampai di hari tuanya nanti. Selain menerapkan pembiasaan pada diri anak harus ada pembuktian seperti contoh dan tauladan. Sebab fitrah manusia baik yang kecil dan dewasa telah mempunyai dorongan meniru dan suka mengindentifikasikan diri terhadap perbuatan dan tingkah laku orang lain terutama orang tua dan pendidik serta teman-teman sebayanya. ${ }^{24}$ Disamping adanya pembiasaan dan contoh/teladan belajar mandiri itu membutuhkan waktu yang sangat lama. Anak sedikit demi sedikit harus diberi penjelasan pentingnya peraturan-peraturan yang dibaut serta menyadarkan nilai-nilai pentingnya sebuah peraturan apabila kesadaran itu talah timbul berarti anak itu mulai mampu untuk memiliki manajemen sendiri serta mampu mengerjakan sendiri tugas-tugas rutinnya, kreatif, inisiatif dalam berfikir dan bertindak, mampu bertanggung jawab dan berkontrol diri dalam memenuhi kebutuhannya sendiri.

\section{KESIMPULAN}

1. Model pendidikan keluarga yang disesuaikan dengan situasi dan kondisi anak serta berdasarkan pada konteks kebutuhan dan kemampuan yang dimiliki oleh anak akan memberikan dampak positif terhadap kondisi psikologis dan kemandirian anak, dengan menerapkan seperangkat aturan, memberikan motivasi dan dukungan, mengajarkan ilmu agama dan mengamalkannya dengan memberikan suri tauladan yang baik.

2. Pola tingkah pada diri anak yang mengarah pada perubahan yang positif merupakan dampak dari penerapan model pendidikan keluarga, sehingga dapat membentuk kepribadian anak menjadi lebih baik hal tersebut dapat terlihat secara signifikan dari tata cara sopan santun terhadap orang tua, mandiri dalam hal ibadah, melakukan apa yang telah dinasihati oleh orang tua, rajin beribadah, taat kepada orang tua, memiliki tanggungjawab, serta memiliki kemandirian yang tinggi.

3. Kendala-kendala yang dihadapi orang tua di dalam penerapan model pendidikan keluarga dari tinjauan waktu, membutuhkan proses yang cukup lama, terutama orang tua yang sibuk dalam bekerja, serta

${ }^{23}$ Hasil wawancara dengan informan penelitian.

${ }^{24}$ Soekanto Soerjono, Sosiologi Keluarga, Jakarta: Rineka Cipta, 1990. Hal: 20 
tidak memiliki disiplin keilmuan dalam membimbing dan mendampingi anak, akan memperlambat perkembangan psikologis dan kemandirian anak. Bagi anak tidak mudah menerima apa yang disampaikan oleh orang tua secara langsung karena membutuhkan proses serta keteladanan dari orang tua.

\section{DAFTAR PUSTAKA}

Ahmadi, Abu dan Ubhiyati, Nur. Ilmu Pendidikan. Jakarta: Rineka Cipta. 1991.

Djamarah, Syaiful Bahri. Pola Asub Orang Tua dan Komunikasi dalam Keluarga. Jakarta: Rineka Cipta. 2014. Emzir. Metode Penelitian kualitatif analisis data, Jakarta: Rajawali Pers. Universitas Sumatera Utara. 2005.

Habsjah Atashendartini. Jender dan Pola Kekerabatan dalam To Ihromi. Jakarta: Yayasan Obor Indonesia. 2004.

Helmawati, Pendidikan Keluarga. PT. Remaja Rosdakarya: Bandung. 2014.

Lexi. J. Moleong. Metodologi Penelitian Kualitatif. Bandung: Remaja Rosda karya. 2000.

Purwanto, Ngalim. Ilmu Pendidikan Teoritis dan Praktis. Bandung: Remaja Rosdakarya. 1991.

Mufidah, Chasanah. Psikologi Keluarga Islam Berwawasan Gender. Malang: UIN Malang. 2008.

Sadulloh, Uyoh. Ilmu Pendidikan Islam. Bandung: Alfabeta. 2003.

Sobur, Alex. Komunikasi Orang Tua \& Anak. Bandung: Angkasa. 1986.

Soekanto, Soerjono. Sosiologi Keluarga. Jakarta: Rineka Cipta. 1990.

Salahuddin Anas Alkrienciehie Irwanto. Pendidikan Karakter Berbasis Agama dan Budaya Bangsa. Bandung: Cv. Pustaka Setia. 2013.

Undang-undang RI. No. 2 Tahun 1989. Tentang Sistem Pendidikan Nasional. Jakarta: Intan Pariwara. 1989. Vrembianto. Sosiologi Pendidikan. Yogyakarta: Gunung Agung. 1990.

Yunuf, Syamsu. Psikologi Perkembangan Anak dan Remaja, Bandung: PT Remaja RosdaKarya. 2005. 